\title{
THE EFFECT OF HYPERTHERMIA ON THE DISTRIBUTION OF WATER AND ELECTROLYTES IN BRAIN, MUSCLE AND LIVER ${ }^{1}$
}

\author{
BY HERMAN YANNET AND DANIEL C. DARROW
}

(From the Department of Pediatrics, Yale University School of Medicine, New Haven)

(Received for publication September 29, 1937)

It is a well recognized clinical observation that young children are prone to have convulsions at the onset of certain acute febrile illnesses. This is much less common in older children, and practically unknown in adults except during hyperthermia of the most marked degree. In some recently completed, but as yet unpublished experiments, Wegman (1) was able to demonstrate that similar reactions were exhibited by cats of various ages when hyperthermia was produced by exposure in a heating cabinet. The observations of some investigators as to the apparent relation of body hydration to the convulsions of epilepsy (2) and those associated with insulin hypoglycemia (3), turned our attention to the distribution of tissue water and electrolytes following hyperthermia.

The purpose of the present investigations was to study the changes in the distribution of water and electrolytes in the brain, muscle and liver of animals of varying sizes, after exposure in a heating cabinet according to the technique developed by Wegman (1). Three problems naturally presented themselves: (1) How do the tissues of the young animal differ from that of the older animal? In other words, what is the effect of growth on the distribution of water and electrolytes in these tissues? (2) What is the effect of hyperthermia on these tissues, and how does this vary in animals of different ages?

Can the convulsions associated with hyperthermia be correlated with any specific changes in the brain?

The first problem propounded, namely the effect of growth on the distribution of water and electrolytes will be discussed in another paper (4). It will suffice at this time to briefly summarize this phase of the problem as follows. The distribution of water in brain, liver and muscle

1 This work was aided by a grant from the fluid research fund of the Medical School. varies according to the age of the animal. In brain and liver, the proportion of the total water represented by the extracellular fluid is slightly smaller, and that represented by the intracellular fluid, slightly larger in the older animals. In muscle, on the other hand, growth is almost entirely due to expansion of the intracellular compartment with very little increase in the absolute amount of extracellular fluid. Thus, in the older animals, the proportion of total water represented by the extracellular fluid is less than one-third that found in very young animals. The percentage of total water in all three tissues when expressed in terms of fat-free tissue, shows very little change in animals of different ages.

The following discussion will confine itself to the effect of hyperthermia on the distribution of water and electrolytes in the brain, muscle and liver of animals of varying ages.

\section{PROCEDURE}

Cats were used as the experimental animals. Since it was impossible, in many instances, to be sure of the exact age, the animals' weight was used as the index of growth. The animals were kept for approximately one week on the usual kennel diet, consisting of canned meat and milk. No food was given the day of the experiment. Water, however, was allowed ad libitum.

Hyperthermia was produced in an elliptical chamber. The source of the heat was a high resistence wire situated at the top of the chamber from which the heat was reflected on to a platform on which the animal was restrained. A detailed description of the apparatus employed will be given in Wegman's paper (1).

Increases in body temperature (rectal) of from $4^{\circ}$ to $6^{\circ} \mathrm{C}$. were obtained after exposures lasting from 30 to 60 minutes. In some of the animals, the temperature was allowed to rise more slowly so that similar degrees of temperature elevation were achieved after exposures lasting up to 5 hours. Upon the onset of convulsions, the animals were removed from the chamber, anesthetized with ether, and killed by exsanguination through a cardiac puncture. A similar procedure was carried out on those animals removed from the chamber before convulsions occurred. The control animals were anesthetized and bled in the same manner as the heated ones. 
The blood was collected under oil, allowed to clot, and the serum removed in the usual manner. The entire liver, and adequate samples of skeletal muscle (from all four extremities) were rapidly removed and collected in weighed, stoppered bottles. The calvarium was carefully removed, and the brain, including the hemispheres, cerebellum and most of the midbrain, delivered in toto into weighed, stoppered bottles. Any visible particles of bone were first wiped away. After being weighed, the bottles containing the various tissues were placed in an oven, at $105^{\circ} \mathrm{C}$., and dried to constant weight. This usually took about 3 to 5 days.

\section{CHEMICAL METHODS}

Water was determined by drying to constant weight in an oven at $105^{\circ} \mathrm{C}$. All tissue analyses were carried out on the dried material, which was first finely ground. Nitrogen was determined by the Kjeldahl method (5); total fat gravimetrically by extraction with hot alcohol and ether for one hour, drying and re-extraction with petroleum ether; chloride, in serum by the method of Van Slyke and Sendroy (5); chloride in tissues, by ashing in a muffle furnace at $420^{\circ} \mathrm{C}$. in the presence of sodium carbonate, extracting the ash with warm water, slightly acidified with nitric acid, and then proceeding by the method of Van Slyke and Sendroy (6) ; sodium, by the method of Butler and Tuthill (5) after removal of potassium as described by Hald (7); potassium, by Hald's modification of the method of Shohl and Bennet (7), except for the final determination of $\mathrm{K}_{2} \mathrm{PTCl}_{6}$ which was determined as chloride after reduction with sodium bisulfite (8) ; phosphorus, by the method of Fiske and Subbarow (9). For sodium, potassium and phosphorus determinations, the material was first ashed in a muffle furnace at $500^{\circ} \mathrm{C}$. in silicon dishes, the subsequent analyses being carried out on aliquots of the dissolved ash.

\section{CALCULATIONS}

The calculations are based on the assumption that all tissue chloride is confined to the extracellular compartment. The formulae, their derivations, and consideration of their validity are given in a previous paper (10). By means of these calculations the extracellular and intracellular water and the concentrations of intracellular potassium, nitrogen and phosphorus were determined.

The statistical analysis followed that described by Dunn (11). The standard error was obtained by the formula $\frac{\alpha}{\sqrt{n-1}}$, where $\alpha$ is the standard deviation and $n$, the number of observations. Where the difference between two means is equal to twice the standard error of the difference, the probability of the difference not being significant is approximately 1 in 20 . Where the difference is three times the standard error, this probability becomes 1 in 300 .

\section{RESULTS}

In Table I, we have summarized the results of the analyses of brain, muscle and liver in the
TABLE I

The average concentration, per kilogram of tissue, of water, ritrogen, chloride, sodium, potassium, and phosphorus in brain, muscle and liver of normal and heated animals

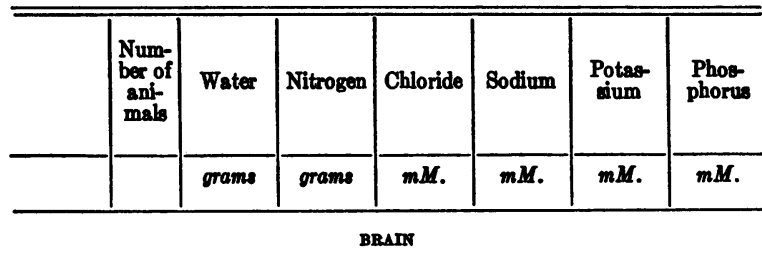

\begin{tabular}{l|c|c|c|c|c|c|c|}
\hline Normal... & 17 & $828 \pm 5.0$ & $15.7 \pm 0.3$ & $41.3 \pm 0.8$ & $53.9 \pm 0.0$ & $87.5 \pm 1.3$ & $86.0 \pm 3.1$ \\
\hline Heated... & 18 & $819 \pm 5.0$ & $16.6 \pm 0.4$ & $46.9 \pm 1.0$ & $61.2 \pm 1.5$ & $89.7 \pm 2.0$ & $89.6 \pm 2.7$ \\
\hline
\end{tabular}

\begin{tabular}{l|c|c|c|c|c|c|c}
\hline Normal... & 20 & $\frac{778 \pm 5.0}{26.7 \pm 0.7}$ & $22.3 \pm 1.7$ & $30.7 \pm 2.0$ & $\frac{84.7 \pm 1.8}{62.4 \pm 1.8}$ \\
\hline Heated... & 18 & $787 \pm 5.0$ & $26.8 \pm 0.6$ & $23.9 \pm 1.8$ & $31.8 \pm 2.4$ & $\frac{87.5 \pm 2.3}{62.4 \pm 2.0}$ \\
\hline
\end{tabular}

\begin{tabular}{l|l|l|l|l|l|l|l}
\hline Normal... & 20 & $719 \pm 8.0$ & $25.3 \pm 0.8$ & $28.5 \pm 2.0$ & $33.8 \pm 1.9$ & $77.2 \pm 1.6$ & $82.3 \pm 2.6$ \\
\hline Heated... & 18 & $740 \pm 5.0$ & $28.4 \pm 0.5$ & $32.0 \pm 1.2$ & $38.9 \pm 1.6$ & $75.3 \pm 2.2$ & $84.4 \pm 3.5$ \\
\hline
\end{tabular}

heated and control animals. For the sake of brevity only the averages and their standard errors are given. Water and nitrogen are expressed as grams, while chloride, sodium, potassium and phosphorus are expressed as millimoles per kilogram of whole tissue. Unfortunately, because of insufficient material, especially in the smaller animals, analysis for fat could not be carried out on every tissue. For this reason, it was not possible to express the results in terms of fat-free material, a procedure which is much to be desired. However, an approximation of the average values for the percentage of fat in the tissues of the normal and heated animals may be obtained from the results of the analyses which were completed. These consisted of about one-half the tissues in each group. Thus, in the brain the average value for fat was 4.5 per cent in both heated and normal animals. In muscle, this was 2.4 per cent in the normal animals and 2.2 in the heated ones. In the liver, there was an appreciable difference, averaging 5 per cent for the normal, and 2.8 per cent for the heated animals. In the table, one may note (1) the significant increases in sodium and chloride in the brains of the heated animals, (2) the absence of any differences in the muscle analyses and (3) the questionably significant increases in sodium, chloride, and water in the livers of the heated animals. 
The significance of these findings can be discussed more readily by means of the following tables which summarize the results of the application of the previously mentioned calculations to the chemical analyses, the averages of which were presented in Table I.

In the subsequent tables, the first column gives the number of animals analyzed in each group. The next three columns give the average values for total water, and its division into extracellular and intracellular compartments. These values are expressed as per cent of tissue weight. The following three columns give the average concentrations of nitrogen in grams, and potassium and phosphorus in millimoles per liter of intracellular water. Because of the differences in the distribution of water in the tissues of normal animals of different weights, care was taken so that the mean, range and distribution of weight of the animals in the control group was approximately the same as in the experimental group.

\section{The effect of hyperthermia on the distribution of water and electrolytes in the brain}

Table II gives a summary of the significant data as regards the changes in the brain incident to hyperthermia. There were 17 animals in the control group and 18 in the heated group.

TABLE II

The distribution of water and electrolytes in the brains of normal and heated animals

\begin{tabular}{|c|c|c|c|c|c|c|c|}
\hline & $\begin{array}{c}\text { Num- } \\
\text { ber of } \\
\text { ani- } \\
\text { mals }\end{array}$ & $\begin{array}{l}\text { Total } \\
\text { water }\end{array}$ & $\begin{array}{c}\text { Extra- } \\
\text { cellular } \\
\text { water }\end{array}$ & $\begin{array}{c}\text { Intra- } \\
\text { cellular } \\
\text { water }\end{array}$ & $\begin{array}{l}\text { Intra- } \\
\text { cellular } \\
\text { potas } \\
\text { sium }\end{array}$ & $\begin{array}{c}\text { Intra- } \\
\text { cellular } \\
\text { nitrogen }\end{array}$ & $\begin{array}{l}\text { Intra- } \\
\text { cellular } \\
\text { phos- } \\
\text { phorus }\end{array}$ \\
\hline Normal... & 17 & $\begin{array}{c}\text { per cent } \\
82.8 \pm 0.5\end{array}$ & $\begin{array}{c}\text { per cent } \\
32.0 \pm 0.8\end{array}$ & $\begin{array}{c}\text { per cent } \\
50.9 \pm 0.6\end{array}$ & $\begin{array}{c}m M . \\
\text { per liter } \\
167 \pm 2.5\end{array}$ & $\begin{array}{c}\text { grams } \\
\text { per liter } \\
31.0 \pm 0.8\end{array}$ & $\begin{array}{c}m M . \\
\text { per liter } \\
173 \pm 5.0\end{array}$ \\
\hline Heated... & 18 & $81.9 \pm 0.5$ & $35.2 \pm 0.9$ & $46.7 \pm 0.8$ & $183 \pm 3.5$ & $35.3 \pm 1.0$ & $190 \pm 6.2$ \\
\hline
\end{tabular}

The changes may be described as follows. There is a slight decrease in total water, a change which, statistically, is only questionably significant. All of the other changes, however, are definitely significant, the differences between the means being at least 3 times or more the standard error of the differences. These include: (1) an increase in the extracellular fluid associated with a quantitatively similar decrease in the intracellular fluid; (2) an increase in the concentration of all the intracellular elements studied. It may also be noted that the proportionate increase in intracellular concentrations is approximately equal to the proportionate decrease in intracellular fluid, signifying, primarily, a shift of water from the latter compartment.

TABLE III

The distribution of water and electrolytes in the brains of normal and heated animals*

\begin{tabular}{c|c|c|c|c|c|c|c}
\hline $\begin{array}{c}\text { Num- } \\
\text { ber of } \\
\text { ani- } \\
\text { mals }\end{array}$ & $\begin{array}{c}\text { Total } \\
\text { water }\end{array}$ & $\begin{array}{c}\text { Extra- } \\
\text { cellular } \\
\text { water }\end{array}$ & $\begin{array}{c}\text { Intra- } \\
\text { cellular } \\
\text { water }\end{array}$ & $\begin{array}{c}\text { Intra- } \\
\text { cellular } \\
\text { nitrogen }\end{array}$ & $\begin{array}{c}\text { Intra- } \\
\text { cellular } \\
\text { potas } \\
\text { sium }\end{array}$ & $\begin{array}{c}\text { Intra- } \\
\text { cellular } \\
\text { phos- } \\
\text { phorus }\end{array}$ \\
\hline & per cent & per cent & per cent & $\begin{array}{c}\text { grams } \\
\text { per liter }\end{array}$ & $\begin{array}{c}m M . \\
\text { per liter }\end{array}$ & $\begin{array}{c}m M . \\
\text { per liter }\end{array}$ \\
\hline
\end{tabular}

300 to 800 grams

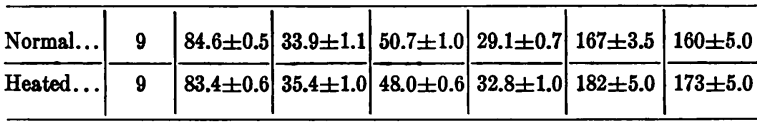

800 to 2500 grams

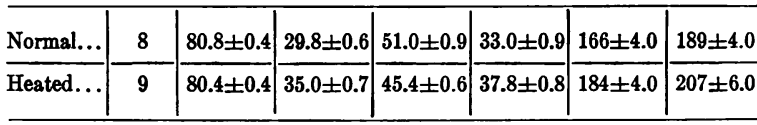

* The table is prepared so that the changes in the young (weighing from 300 to 800 grams) and older animals (weighing from 800 to 2500 grams) may be compared.

Table III was constructed in order to determine whether these changes were present in equal degree in the younger and older animals. The table is prepared in the usual manner. The normal and heated animals were divided into two groups, those up to 800 grams in weight and those from 800 up to and above 2500 grams. The average values and standard errors are given for the distribution of water and concentration of intracellular electrolytes. It will be seen that both groups show the same changes that were described above for the total group, namely, a shift of water from the intracellular to extracellular compartment with a consequent concentration of the intracellular elements. At present no reason can be given for the fact that the changes are somewhat less in the younger animals although the direction of the changes are the same.

Table IV was prepared in order to determine the relationship of the convulsions to the changes in the brains of the heated animals. Of the heated animals there were 8 that did not have convulsions and 10 that did. From the latter group, 8 were selected so that the mean weight and distribution was approximately the same as in the non-convulsive group. The table is similar to the previous 
TABLE IV

The distribution of water and electrolytes in the brains of the heated animals having convulsions compared with those not convulsing

\begin{tabular}{|c|c|c|c|c|c|c|c|}
\hline & $\begin{array}{c}\text { Num- } \\
\text { ber of } \\
\text { ani- } \\
\text { mals }\end{array}$ & $\begin{array}{l}\text { Total } \\
\text { water }\end{array}$ & $\begin{array}{l}\text { Extra- } \\
\text { cellular } \\
\text { water }\end{array}$ & $\begin{array}{l}\text { Intra- } \\
\text { cellular } \\
\text { water }\end{array}$ & $\begin{array}{l}\text { Intra- } \\
\text { cellular } \\
\text { potas- } \\
\text { sium }\end{array}$ & $\begin{array}{c}\text { Intra- } \\
\text { cellular } \\
\text { nitrogen }\end{array}$ & $\begin{array}{l}\text { Intra- } \\
\text { cellular } \\
\text { phos- } \\
\text { phorus }\end{array}$ \\
\hline $\begin{array}{l}\text { Convul- } \\
\text { sions... }\end{array}$ & 8 & $\begin{array}{c}\text { per cent } \\
81.9 \pm 0.5\end{array}$ & $\begin{array}{l}\text { per cent } \\
35.5 \pm 1.2\end{array}$ & $\begin{array}{l}\text { per cent } \\
46.6 \pm 1.0\end{array}$ & $\begin{array}{c}m M . \\
\text { per liter } \\
185 \pm 3.5\end{array}$ & $\begin{array}{c}\text { grams } \\
\text { per liter } \\
35.9 \pm 1.2\end{array}$ & $\begin{array}{c}m M . \\
\text { per liter } \\
186 \pm 5.0\end{array}$ \\
\hline $\begin{array}{l}\text { No con- } \\
\text { vulsions }\end{array}$ & 8 & $80.7 \pm 0.5$ & $33.2 \pm 1.1$ & $47.5 \pm 0.9$ & $185 \pm 4.0$ & $36.1 \pm 0.9$ & $202 \pm 8.0$ \\
\hline
\end{tabular}

ones, and includes the average values and standard errors of the distribution of water and concentration of intracellular elements. It will be noted that there are no significant differences between the groups.

Confirmatory evidence indicating a diminution in cellular water in the brains of the heated animals can be seen in Figure 1, which is a microphotograph comparing the histological changes in the brain of a heated animal with that of a normal one. $^{2}$ The section on the left is from the cortex of a normal animal of an age similar to that of the heated animal whose cortex is represented on the right. We merely wish to indicate at this time that the striking change in the ganglion cells is a shrinking of the cell bodies, manifested by actual diminution in diameter and an increase in staining capacity. A more detailed report of the pathological changes found during hyperthermia will be presented elsewhere (1).

\section{The effect of hyperthermia on the distribution of water and clectrolytes in muscle}

Table $\mathrm{V}$ shows the effect of hyperthermia on the distribution of water and electrolytes in muscle. Statistically, there is no significant difference between the control and heated groups. The agreement, it will be noted, is exceedingly good, considering the nature of the calculations involved.

${ }^{2}$ We wish to thank Dr. H. M. Zimmerman of the Department of Pathology for preparing the histological sections and aiding in their interpretation.

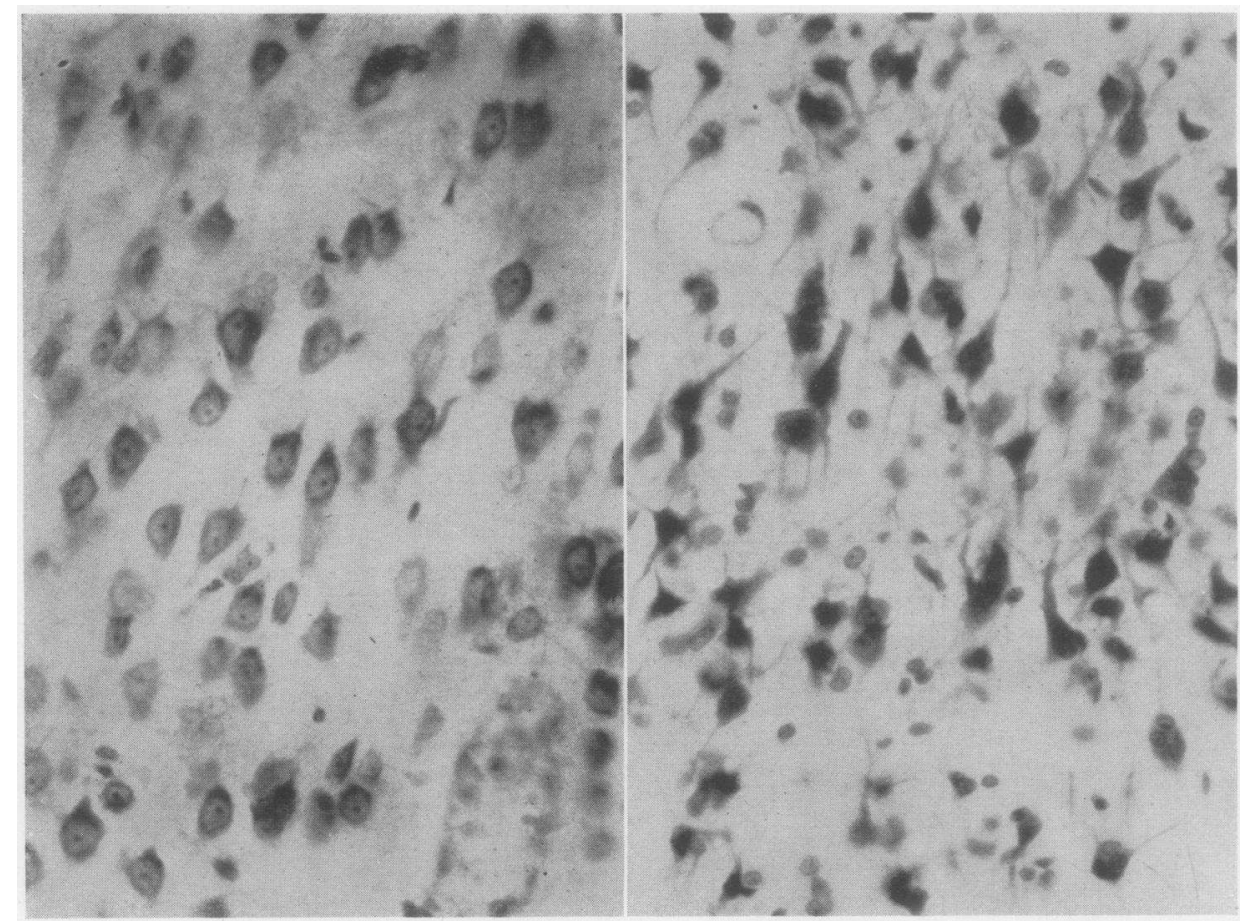

Fig. 1. Microphotograph of Histological Sections from the Cortex of a Normal and a Heated Animal of Similar Age.

The sections were taken from an approximately similar location in each brain. That on the left is from the normal animal. 
TABLE V

The distribution of water and electrolytes in the muscles of normal and heated animals

\begin{tabular}{|c|c|c|c|c|c|c|c|}
\hline & $\begin{array}{l}\text { Num- } \\
\text { ber of } \\
\text { ani- } \\
\text { mals }\end{array}$ & $\begin{array}{l}\text { Total } \\
\text { water }\end{array}$ & $\begin{array}{l}\text { Extra- } \\
\text { cellular } \\
\text { water }\end{array}$ & $\begin{array}{l}\text { Intras } \\
\text { cellular } \\
\text { water }\end{array}$ & $\begin{array}{l}\text { Intra- } \\
\text { cellular } \\
\text { potas } \\
\text { sium }\end{array}$ & $\begin{array}{l}\text { Intra- } \\
\text { cellular } \\
\text { nitrogen }\end{array}$ & $\begin{array}{l}\text { Intra- } \\
\text { cellular } \\
\text { phos- } \\
\text { phorus }\end{array}$ \\
\hline Normal... & 20 & $\begin{array}{c}\text { per cont } \\
77.8 \pm 0.5\end{array}$ & $\begin{array}{c}\text { per cent } \\
17.3 \pm 1.3\end{array}$ & $\begin{array}{c}\text { per cont } \\
60.6 \pm 1.2\end{array}$ & $\begin{array}{c}m M . \\
\text { per liter } \\
138 \pm 2.2\end{array}$ & $\begin{array}{c}\text { grams } \\
\text { por liter } \\
4.1 \pm 0.7\end{array}$ & $\begin{array}{c}\text { m.M. } \\
\text { per liter } \\
103 \pm 1.8\end{array}$ \\
\hline Heated... & 18 & $78.7 \pm 0.5$ & $18.1 \pm 1.4$ & $60.6 \pm 1.0$ & $142 \pm 3.0$ & $44.1 \pm 0.7$ & $103 \pm 3.0$ \\
\hline
\end{tabular}

Furthermore, in the heated group no significant differences could be demonstrated between the convulsant and non-convulsant animals. Moreover, no differences were noted in the reactions of the animals of different ages.

\section{The effect of hyperthermia on the distribu- tion of water and electrolytes in the liver}

Table VI is a summary of the data comparing the water and electrolyte distribution in the livers

TABLE VI

The distribution of water and electrolytes in the livers of normal and heated animals

\begin{tabular}{|c|c|c|c|c|c|c|c|}
\hline & $\begin{array}{l}\text { Num- } \\
\text { ber of } \\
\text { ant- } \\
\text { mals }\end{array}$ & $\begin{array}{l}\text { Total } \\
\text { water }\end{array}$ & $\begin{array}{c}\text { Extra- } \\
\text { cellular } \\
\text { water }\end{array}$ & $\begin{array}{c}\text { Intra- } \\
\text { cellular } \\
\text { water }\end{array}$ & $\begin{array}{l}\text { Intra- } \\
\text { cellular } \\
\text { potas- } \\
\text { sium }\end{array}$ & $\begin{array}{l}\text { Intra- } \\
\text { cellular } \\
\text { nitrogen }\end{array}$ & $\begin{array}{l}\text { Intra- } \\
\text { cellular } \\
\text { phos- } \\
\text { phorus }\end{array}$ \\
\hline Normal... & 20 & $\begin{array}{c}\text { per cent } \\
71.9 \pm 0.8\end{array}$ & $\begin{array}{c}\text { per cent } \\
22.9 \pm 0.8\end{array}$ & $\begin{array}{c}\text { per cent } \\
49.1 \pm 0.8\end{array}$ & $\underset{\text { per liter }}{m M .}$ & $\begin{array}{c}\text { grams } \\
\text { per liter } \\
51.3 \pm 1.6\end{array}$ & $\begin{array}{c}\text { mM. } \\
\text { per liter } \\
168 \pm 5.0\end{array}$ \\
\hline Heated... & 18 & $74.0 \pm 0.5$ & $24.5 \pm 0.7$ & $49.6 \pm 0.8$ & $147 \pm 1.1$ & $57.2 \pm 1.9$ & $171 \pm 7.0$ \\
\hline
\end{tabular}

of the heated and control animals. Unfortunately, as was previously stated, fat determinations could only be carried out on approximately half the tissues of each group. The average fat values, of those done, were 5 per cent for the normal group and 2.8 per cent for the heated group. If this represents the true difference in the groups as a whole, the changes in total water and extracellular water may be attributed to this factor. The remaining changes are probably not significant, except for the concentration of intracellular potassium which suggests a real loss of potassium from the liver cell as a result of heating. There were, also, no significant differences between the convulsant and non-convulsant animals in the heated group, or among the animals of different ages.

\section{The effect of hyperthermia on the concentra-} tion of serum electrolytes and water

Table VII gives the averages and standard errors of the concentrations of chloride, sodium,

\section{TABLE VII}

The concentrations of chloride, sodium, potassium, water and protein in the sera of normal and heated animals

\begin{tabular}{l|c|c|c|c|c|c}
\hline \hline & $\begin{array}{c}\text { Num- } \\
\text { ber of } \\
\text { ani- } \\
\text { mals }\end{array}$ & Chloride & Sodium & Potassium & Water & Protein \\
\hline & $\begin{array}{c}\text { mM. per } \\
\text { liter }\end{array}$ & $\begin{array}{c}\text { mM. per } \\
\text { liter } \\
\text { Normal .. }\end{array}$ & $\begin{array}{c}116 \pm 0.7 \\
152 \pm 1.1\end{array}$ & $\begin{array}{c}\text { mM. per } \\
\text { liter } \\
8.6 \pm 0.5\end{array}$ & $\begin{array}{c}\text { per cent } \\
94.2 \pm 0.1\end{array}$ & $\begin{array}{c}\text { per cent } \\
5.5 \pm 0.2\end{array}$ \\
\hline Heated... & 18 & $118 \pm 1.2$ & $\frac{152 \pm 2.0}{11.3 \pm 0.5}$ & $93.6 \pm 0.3$ & $6.6 \pm 0.2$ \\
\hline
\end{tabular}

potassium, water and protein in the serums of the control and heated animals. A significant increase in serum potassium can be noted in the heated animals. (This confirms the findings of KallosDeffner (12).) The increase in serum protein and decrease in serum water are also probably significant. There are no changes in the concentrations of chloride and sodium.

\section{DISCUSSION}

While no significant changes can be demonstrated in the distribution of water in muscle and liver as a result of hyperthermia, the effect on the brain is quite definite. This consists of a redistribution of water, involving a shift from the brain cells to the extracellular compartment. This water shift is apparently unaccompanied by any of the intracellular elements investigated.

In Table I, it was noted that the only significant change found in the brains of the heated animals was an increase in sodium and chloride. There was little, if any, change in the total water and no change in nitrogen, potassium and phosphorus. Since sodium and chloride are extracellular ions, and since the concentrations of these two elements in the serum did not change, it is apparent that an increase in the quantity of extracellular fluid must have taken place. In the presence of a constant amount of total water, this increase could only be brought about by a shift of water from the cells. This water, equilibrating with the extracellular fluid of the body, would therefore account for the increased content of sodium and chloride in the brain. 
Since the term " edema" ordinarily implies an increase in extracellular fluid, one may rightfully consider the change as one of "brain edema." However, it differs from the usual type of edema in other tissues, in that the total water shows little change and changes within the cells are probably primary.

As pointed out in previous papers $(13,10)$ the distribution of water between the intracellular and extracellular phases is largely dependent on the distribution of potassium and sodium in these phases. Thus, a decrease in concentration of sodium in extracellular fluid should be accompanied by a decrease in the amount of water in the extracellular fluids and an increase in that of the intracellular fluids. Conversely, an increase in concentration of sodium in extracellular fluids will result in a shift of water out of the cells into interstitial spaces. These changes are necessary to equalize the osmotic pressures of the two phases of body water if other factors remain the same.

In the brains of the hyperthermic cats, despite the lack of appreciable changes in concentration of extracellular sodium or changes in the total amount of potassium in the brain, a shift of water from the brain cells to the extracellular spaces was demonstrated. Such a result must have been initiated by a decrease in the osmotic pressure within the cells. Since the osmotic pressure of intracellular fluids is largely determined by the concentration of potassium, the activity of this ion must have changed. Presumably about one-third of the potassium of cells is combined with proteins, onethird with organic phosphates and one-third with a heterogeneous group of anions. Conceivably one or several of these combinations are changed from largely dissociated to largely undissociated combinations either by some alteration produced by a rise in temperature or some metabolic process induced by fever. Whatever the mechanism, the cells of the liver and muscle are absolutely or relatively unaltered while the brain is quite susceptible to the change.

The brain is peculiar in that the concentration of intracellular protein is the lowest of any tissue examined, being somewhat more than half the concentration in muscle or liver and about one-third that in erythrocytes. Conceivably a rise in temperature alone may induce changes in the combination of brain proteins and salts. On the other hand, an alkalosis induced by overbreathing in hyperthermia (14 to 20) might initiate the changes. However, without more knowledge of the factors affecting the base-combining properties of cellular proteins, further speculation is not justified. Analogous changes in the other combinations could equally well explain the shift in water.

Recently, it has become clear that the salts of intracellular fluid form quite variable combinations. Yannet, Darrow and Cary (21) found in experiments of short duration that the concentration of sodium in serum predicted the concentration of sodium plus potassium in erythrocytes in dogs, monkeys and rabbits. In some of the experiments on dogs by the above investigators (unpublished), when sodium had been made to shift into the red cells in response to an increase in serum sodium, the cellular sodium was found to remain high with respect to solids after the serum sodium had returned to the normal level. Eisenman, Hald and Peters (22) found in patients that the red cells responded to changes in concentration of serum base by shifts of water which would indicate that the erythrocytes are perfect osmometers. Nevertheless, changes in concentration of base within the cells occurred independently of changes in concentration of extracellular base. Harrison and Darrow (23) demonstrated analogous changes in muscle cells of adrenalectomized rats. Here, while the total solids of muscle correlated with the concentration of serum sodium, a large increase of cellular potassium occurred despite a decrease in concentration of extracellular sodium. In another series of experiments (24) involving balance studies following the production of sodium chloride deficits, it was demonstrated that large retentions of potassium occurred, unaccompanied by changes in body water or concentration of sodium in serum. While the distribution of body water between intracellular and extracellular phases must be determined by the distribution of sodium and potassium, a number of factors affect the activity of base in the cells. Hence the above statement should be regarded primarily as a first approximation.

At present, the changes in the brain cells cannot be directly related to the convulsions, although such a relationship is a most suggestive possibility. That other factors are also involved is suggested by the fact that similar changes in the brain are 
found in those animals which did not have convulsions. An examination of the present data to determine whether the length of time of exposure in the cabinet was related to the occurrence of convulsions did not bear this out. Neither was the absolute elevation of temperature the deciding factor. In this connection, it is interesting to note that Wegman (1) found that animals of the same weight which would have convulsive seizures if their body temperatures were elevated very rapidly, are less likely to convulse if a similar elevation in body temperature is induced very slowly.

The data throw little light on our original question, namely, why the young child (as well as the young animal (1)) is more likely to have a convulsion with the rapid elevation of body temperature, than the older individual. Changes of a similar nature were found, in this study, in both the older and younger groups. The explanations ordinarily given for this tendency have made use of such ill-defined considerations as "maturation of the central nervous system" and "protective action of myelin." Our data, unfortunately, is of little help in this respect.

Clinically, the effect of exposure to abnormally high external temperatures manifests itself primarily in two ways. In the first, the body maintains a normal temperature, mainly through excessive sweating, which results in the loss of considerable quantities of sodium chloride and water. If this is not replaced, a condition known as heat cramps ensues, involving spasm of many of the voluntary muscles of the body. This condition is completely relieved or may be prevented by the administration of adequate amounts of saline solution. When the above regulatory mechanism is inadequate, the body temperature will rise to extremely high levels, often 108 to $109^{\circ} \mathrm{F}$. Under these conditions, evidences of injury to the central nervous system appear in the form of delirium, convulsions and coma. Recovery is prolonged and difficult and sequelae in the nature of hemiplegias and paraplegias have been reported (25). It is in conditions of this kind that one would expect to find histological changes in the brain similar to those described in the present study. We have been unable to find any pathological reports in the literature bearing on this point. Zimmerman (26) has recently had occasion to study the brains from two adult patients, both of whom died about 3 days after an uncontrolled hyperpyrexia following the application of mechanical fever therapy. The histological changes in these brains were similar to those found in the experimentally heated animals.

\section{SUM MARY}

The effect of hyperthermia on the distribution of water and electrolytes in brain, liver and muscle of cats of various ages, was investigated. The following results were obtained.

1. In the brain, hyperthermia results in a redistribution of water, involving a shift of water from cells to the extracellular fluid, without change in total water. The shift of water is unaccompanied by loss of intracellular potassium, nitrogen or phosphorus. The concentrations of these substances, therefore, are increased in the cells. However, the concentrations of sodium and chloride in the extracellular fluid remain unchanged. Confirmation of this shrinking in cell volume is obtained from histological examination of the brains of the heated animals.

2. The changes in the brain, as described above, could be demonstrated in the animals that convulsed as well as those not convulsing as a result of hyperthermia.

3. The same changes could be demonstrated in both young and older animals exposed to hyperthermia.

4. No significant changes could be demonstrated in the liver or muscle as a result of hyperthermia.

\section{BIBLIOGRAPHY}

1. Wegman, M. C., The factors influencing the production of convulsions following hyperthermia. (To be published.)

2. McQuarrie, I., Epilepsy in children. The relationship of water balance to the occurrence of seizures. Am. J. Dis. Child., 1929, 38, 451.

3. Drabkin, D. L., and Ravdin, I. S., Mechanism of convulsions in insulin hypoglycemia; inter-relationship of blood concentration, cerebrospinal pressure and convulsions. Am. J. Physiol., 1937, 118, 174.

4. Yannet, H., and Darrow, D. C., The effect of growth in the distribution of water and electrolytes in brain, muscle and liver. (To be published.)

5. Peters, J. P., and Van Slyke, D. D., Quantitative Clinical Chemistry. II. Methods. Williams and Wilkins Co., Baltimore, 1932.

6. Official and tentative methods of analysis. Association of Official Agricultural Chemists. Washington, D. C., 1930, p. 249. 
7. Hald, P. M., The determination of the bases of serum and whole blood. J. Biol. Chem., 1933, 103, 471.

8. Harrison, H. E., and Darrow, D. C., The determination of potassium in biological materials. J. Biol. Chem., 1937, 121, 631.

9. Fiske, C. H., and Subbarow, Y., The colorimetric determination of phosphorus. J. Biol. Chem., 1925, 66, 375.

10. Harrison, H. E., Darrow, D. C., and Yannet, H., The total electrolyte content of animals and its probable relation to the distribution of body water. J. Biol. Chem., 1936, 113, 515.

11. Dunn, H. L., Application of statistical methods in physiology. Physiol. Rev., 1929, 9, 275.

12. Kallos-Deffner, L., Uber Kaliumgehalt des Blutserums im Fieber. Acta med. Scandinav., 1935, 85, 221.

13. Darrow, D. C., and Yannet, H., The changes in the distribution of body water accompanying increase and decrease in extracellular electrolyte. J. Clin. Invest., 1935, 14, 266.

14. Cajori, F. A., Crouter, C. Y., and Pemberton, R., The effect of therapeutic application of external heat on the acid-base equilibrium of the body. J. Biol. Chem., 1923, 57, 217.

15. Landis, E. M., Long, W. L., Dunn, J. W., Jackson, C. L., and Meyer, U., Studies on the effects of baths on man. III. Effects of hot baths on respiration, blood and urine. Am. J. Physiol., 1926, 76, 35.

16. Koehler, A. F., Acid-base equilibrium. I. Clinical studies in alkalosis. Arch. Int. Med., 1923, 31, 590.
17. Bazett, H. C., and Haldane, J. B. S., Some effects of hot baths on man. J. Physiol., 1921, 55, iv.

18. Bischoff, F., Long, M. L., and Hill, E., Studies in hyperthermia. II. The acid-base equilibrium in hyperthermia induced by short radio waves. J. Biol. Chem., 1931, 90, 321.

19. Daly, C. A., and Knudson, A., The acid-base equilibrium and phosphorous metabolism in hyperthermia. J. Biol. Chem., 1932, 97, lvii.

20. Danielson, W. H., and Stecher, R. M., Acid-base balance of blood in hyperthermia. Proc. Soc. Exper. Biol. and Med., 1935, 32, 1015.

21. Yannet, H., Darrow, D. C., and Cary, M. K., The effect of changes in the concentration of plasma electrolytes on the concentration of electrolytes in the red blood cells of dogs, monkeys and rabbits. J. Biol. Chem., 1936, 112, 477.

22. Eisenman, A. J., Hald, P. M., and Peters, J. P., Osmotic adjustments between cells and serum in the circulating blood of man. J. Biol. Chem., 1937, $118,289$.

23. Harrison, H. E., and Darrow, D. C., The distribution of body water and electrolytes in adrenal insufficiency. J. Clin. Invest., 1938, 17,

24. Darrow, D. C., and Yannet, H., Metabolic studies of the changes in body electrolyte and distribution of body water induced experimentally by deficit of extracellular electrolyte. J. Clin. Invest., 1936, 15, 419.

25. Talbott, J. H., Heat cramps. Medicine, 1935, 14, 323. 26. Zimmerman, H. M. Personal communication. 